\title{
Religação dos aspectos de natureza e cultura na formação humana
}

\section{Rita Ribeiro Voss $^{1}$}

\section{Resumo}

O artigo reflete sobre formação humana a partir da antropologia, isto é, como pensamento de religação de natureza e cultura na educação. Para isso, retoma os conceitos de cultura ao longo do desenvolvimento da antropologia em dois fronts de pensamento antropológico, o universalista e o relativista. No entanto, ao contrário dos impasses que dividem a antropologia, a formação humana requer que pensemos a condição humana de forma unidual, sendo, ao mesmo tempo, natureza e cultura. O processo de hominização do sapiens, que resultou de seu longo processo evolutivo, forjou a cultura e a criação de universos simbólicos configurados em sociedades diferentes. $\mathrm{Na}$ perspectiva complexa da antropologia, os humanos são considerados em sua dupla condição, em sua hibridez e simultaneidade, de natureza e de cultura (inscrição universal), assim como também como produtos de culturas particulares (inscrição relativa). A formação humana sustentada pela antropologia compõe o que Morin chamou de antropoética.

Palavras-chave: Epistemologia; Formação Humana; Religação; Antropoética.

\begin{abstract}
The article reflects on human formation from Anthropology, that is, as a thought of reconnection of the human aspects of nature and culture in education. With this aim, the work resumes the concepts of culture throughout the development of the Anthropology in two fronts of anthropological thought, the universalist and relativist. However, in opposite to the impasses that divide anthropology, the human formation requires that we think on the human condition in a unified way, at the same time, nature and culture. The process of sapiens' hominization which resulted from their long evolutionary process forged the culture as human creation of different symbolic universes in different societies. From the complex perspective of the Anthropology, humans are considered in dual condition, in their hybridity and simultaneity of nature and culture (universal inscription) also as products of particular cultures (relative inscription). The human formation sustained by the Anthropology composes what Morin called Anthropoetics.
\end{abstract}

Keywords: Epistemology; Human formation; Recreation; Anthropoetics.

\footnotetext{
${ }^{1}$ Antropóloga, professora no Centro de Educação da Universidade Federal de Pernambuco.
} 


\section{Introdução}

$$
\begin{aligned}
& \text { A linguagem mais liberada de restrições } \\
& \text { prosaicas, mais inclinada por essa razão a } \\
& \text { celebrar-se nas férias poéticas, é a mais } \\
& \text { disponivel para tentar dizer o segredo das } \\
& \text { coisas. }
\end{aligned}
$$

Paul Ricouer

ara falar de formação humana, concebo educação a partir do que
chamei em alguns trabalhos de "comunidade de vida", lócus da
experiência humana na Terra, compreendendo que os saberes se engendram nas teias da vida; que os nexos entre conhecimento e contexto dão consistência e pertinência aos objetivos e às ações educativas. A defesa de um conhecimento encarnado está ancorada nas minhas pesquisas que tratam da cognição humana e nos trabalhos de meus orientandos sobre modelos cognitivos em algumas tradições. Acredito que os modelos cognitivos tradicionais podem iluminar as questões contemporâneas de nossas sociedades relacionadas à organização social, às narrativas religiosas, aos sistemas econômicos e aos modos particulares e individuais de ser e de existir. Foi o que fez Lévi-Strauss (2011) em suas palestras no Japão, cujo tema principal foi a contribuição da antropologia com relação aos problemas modernos.

A educação é um fato da existência social, quer consideremos as sociedades sem escrita, ou simples, quer consideremos as sociedades complexas. Ao pensar antropologicamente a educação, caímos na tentação de tomar, de forma universal, princípios e concepções de uma sociedade particular que são relativos e só compreensíveis ao considerarmos o desenvolvimento do pensamento ocidental. Ao contrário disso, todas as sociedades educam segundo padrões específicos de suas culturas, no entanto, uma experiência humana pode cooperar no entendimento e enfretamento de impasses de outras sociedades porque todas têm que responder ao desafio de suas existências cotidianas. Em suma, as experiências humanas podem ser intercambiáveis. 
Contudo, é inegável a consolidação da visão hegemônica de mundo ocidental na educação contemporânea. Sua narrativa de origem encontra-se na filosofia da Grécia Antiga, que fundou um sistema de pensamento tido como legítimo, o qual passou a configurar uma "verdade", a do logos, no pensamento filosófico e, posteriormente, a razão da ciência. Esses saberes particulares foram ocidentalizando o mundo ao longo da história do Ocidente e, através de dominação física e simbólica, hegemonizando sua "verdade".

Não há concorrência com esses saberes nas escolas, ainda que se abram espaços para o conhecimento de culturas em atividades que, embora estejam inseridas nos currículos, são suplementares ou praticadas de maneira distorcida nos chamados temas transversais. Apoiados na "lógica" ocidental, cabe aos educadores estabelecerem guias, os quais redundam em modelos formais e abstratos nas mais variadas áreas do conhecimento. O objetivo desse esforço é preparar as pessoas para atuarem numa sociedade voltada para o desenvolvimento tecnológico e para o mercado.

Ainda que haja um pensamento educacional crítico sobre as expectativas da educação, ele se faz no interior desse sistema educacional e, por isso, é difícil ultrapassá-lo. Para superar os modelos educativos ocidentais já esgotados em suas possibilidades humanas, ter-se-ia que assumir uma perspectiva alargada de educação, pois nisso reside a pertinência do conhecimento antropológico para a educação: pensar a formação humana sob outras perspectivas culturais requer admitir e abrigar outros saberes de culturas tradicionais.

Reconheço, no entanto, que a antropologia não escapa de um etnocentrismo que ela gostaria de evitar, já que não é possível escapar da herança do conhecimento filosófico-científico do Ocidente, no qual seu pensamento se inscreve. Mas, ao relativizar o sentido e a importância das culturas, ainda que não possa desviar-se da construção de uma narrativa ocidental, ela busca um posicionamento simétrico. Entre ela e seu "objeto" existem senhas de acesso à alteridade através das quais as sociedades ocidentais buscam e podem não apenas compreender outras culturas como também a si mesmas. A contribuição antropológica para a educação começa 
por um ensinamento que a constitui como ciência, o de que os humanos em sua dupla condição, em sua hibridez e simultaneidade, de natureza e cultura ${ }^{2}$ (inscrição universal) são, também, produtos particulares de culturas particulares (inscrição relativa).

Mas, há ainda uma dimensão sem a qual não é possível falar de educação, que passa ao largo da razão técnico-científica; a educação é, sobretudo, um campo de valores. Em que medida, então, a perspectiva antropológica pode ser a base de nossas reflexões éticas? As sociedades elaboram padrões morais, conscientes ou inconscientes, que transmitem por códigos escritos, pela experiência e/ou por imitação, para atingir o comportamento social esperado de seus membros. As culturas, por sua vez, trabalham para que características particulares aceitáveis marquem as ações e interações sociais de seus membros. No que se refere às sociedades complexas, a noção de antropoética de Edgar Morin abriga a condição humana no mundo, que a antropologia se encarrega de explicitar, no domínio do inefável, da criação e da experiência.

As considerações a seguir refletem sobre o papel da antropologia da educação na formação humana entendida como processo e, ao mesmo tempo, emergente e imanente à experiência humana. Primeiro discuto a noção de formação humana; em seguida, reviso os conceitos de "Cultura" e "culturas" desenvolvidos ao longo da história do conhecimento antropológico, que implicam a ideia de socialização ou endoculturação. Discuto também a espiritualidade humana como domínio das representações culturais imanentes à vida, já que a vida do espírito é ela mesma cultural. Por fim, reflito sobre formação humana de um ponto de vista mais amplo, o da antropologia

\footnotetext{
${ }^{2}$ Para Lévi-Strauss (2009), não é possível separar natureza e cultura, mas ao comparar os homens com outros primatas, os chimpanzés, ele constatou que há uma diferença crucial entre eles e que esta funda a cultura. $\mathrm{O}$ antropólogo observou que as relações sexuais entre esses primatas não eram regradas, ao contrário das relações entre os homens regidas pela proibição do incesto. A regra inaugura e, ao mesmo tempo, caracteriza a cultura como algo exclusivamente humano, sabendo-se que todas as sociedades estabelecem regras, a partir da proibição do incesto, para a maioria das práticas humanas. Mas se o tabu do incesto é universal, o estabelecimento de regras é particular. Cada sociedade escolhe seus códigos e leis de convivência, do que se pode ou não fazer, quer sejam explícitas em um código escrito nas sociedades complexas, com a criação de sistemas jurídicos, quer sejam na forma de praxe ou costume, como nas sociedades simples.
} 
complexa, como refundação do pensamento pedagógico no mundo contemporâneo.

\section{Formação humana}

Começo esse artigo com uma constatação e, ao mesmo tempo, com uma esperança, ambas retiradas da obra Jorge Larossa (2005). Para o autor, formação é uma palavra em desgraça e anacrônica, mas ele afirma: “Às misérias de nosso presente só podemos lhe opor, agora, uma ideia caída. Mas talvez, enquanto caída, cheia de possibilidades" (p. 79). Justamente por essas possibilidades é que se pode construir uma educação por saberes e por poéticas mais comprometidas com as questões humanas da vida.

Implícita na queda da noção de formação humana de que fala Larossa está a descrença na educação burguesa, que idealizou um homem superior, mas que, na verdade, prepara-o para habitar um mundo construído sob a égide da ciência e do mercado e para a subserviência ao Estado. Ainda assim, persiste uma questão educativa maior sobre o humano no centro de sua existência, como homens e mulheres reais, plenos de vida, mas também imponderáveis e cheios de incertezas. Como trazer à dimensão apolínea de suas existências, a dimensão poética? Almejar que esses homens e mulheres concretos em suas dimensões emocionais, pulsionais, tidas como inferiores, comparadas à razão, parece-me fundamental. Nesse sentido, nada que é humano é estranho, mas concorre para a sua compreensão.

Segundo Ilya Prigogine, químico e pensador, mesmo na ciência, as instâncias afetivas, emocionais, e o imaginário, abrigo dos sonhos, são motores para a elaboração de teorias. Prigogine (2001, p. 101) afirmou que o que sabemos sobre a natureza, ao contrário de um entendimento estritamente racional, é apreendido por dimensões comumente não reconhecidas pelo pensamento acadêmico redutor. Ao contrário, o conhecimento científico, para ele, é "um processo aberto de produção e invenção dentro de um mundo aberto, produtivo e inventivo".

Embora essas instâncias não racionais sejam fontes de energia livre e criativa para produzir o que a razão totalmente regulamentada é incapaz de 
conceber, raras vezes elas são consideradas como parte inseparável do conhecimento. Edgar Morin (1997), ao refletir sobre o conhecimento, usa a palavra demens para traduzir o complexo de sonhos, desejos, irracionalidades, instâncias que interagem, dentro de um imaginário fértil, de onde emergem modelos criativos. A formação humana, para além de uma compreensão estritamente formal do que é conhecimento, precisa reconhecer as dimensões sensíveis que a constituem.

Essas instâncias sensíveis da existência humana se inscrevem num domínio biológico, na configuração biológica da espécie, portanto, no domínio material da existência. Nosso imaginário, nossas fabulações e teorizações emergem de um cérebro humano que resultou de um longo processo evolutivo, potencialmente apto para planejar, imaginar e teorizar. Portanto, na formação humana, a dimensão poética, dionisíaca é, ao mesmo tempo, encarnada, sensível, assim como coexiste e interage com nossa instância apolínea. A idealização do humano, no entanto, reduziu-o à sua racionalidade, amputando sua dimensão sensível da vida, e o representou unidimensionalmente em uma forma particular de compreensão e de apreensão da realidade.

Essas afirmações sobre a dimensão sensível do conhecimento são claramente opostas ao modelo construído através do desenvolvimento do pensamento ocidental, abstraído da natureza, da vida e da experiência, com o qual as crianças e jovens aprendem formalmente a pensar. Ao contrário, o entendimento da condição humana unidual, natural e cultural, acoplada no mundo e na experiência e, ao mesmo tempo, nas elaborações culturais a partir desse acoplamento, poderia, por exemplo, ensinar às crianças, de forma consistente, que sua vida está implicada na natureza. Pensemos, a partir disso, sobre as implicações para a vida cotidiana, o que significaria, em termos de vida para o planeta exaurido pelo esgotamento dos recursos naturais, um consumo consciente de produtos.

No entanto, as formas de pensar do Ocidente estão intimamente relacionadas a operações que primeiro descontextualizam algo para, em seguida, contextualizá-lo no pensamento em uma representação 
desencarnada. A educação ocidental não sobrevive sem guias, sem manuais para "conhecer" um objeto a partir de sua representação e não de sua inserção no mundo. Estudantes podem fazer uma excursão à floresta para conhecer uma planta, mas não é absolutamente necessário, uma vez que um guia é mais recomendado, pois lá está sua classificação e todo o conhecimento acumulado sobre o vegetal. A planta em sua realidade fenomenal não importa tanto.

Essa operação mental que prioriza as abstrações incita a fazer um contraste com modelos cognitivos encarnados de outras tradições humanas, que se utilizam da experiência para retirar conhecimento para a existência. Mas cabe uma relativização: o que aqui discuto não é o total abandono da educação ocidental, mas sim a possibilidade de que outras formas de conhecer a possam inspirar a partir da perspectiva antropológica. Nesse sentido, a questão para a antropologia da educação seria: que respostas podemos buscar nas mais variadas culturas, para além do quadrado racional-tecnológico ocidental, no enfrentamento de problemas vivenciados pelas sociedades modernas ocidentais? Os saberes da tradição indígena, por exemplo, encontram em sua organização social uma forma poética de ensinar por meio da relação mítica e ritual com sua ancestralidade e o meio mais imediato. Quem pode ensinar a apreciação da vida atual, que nem sequer é tangenciada na escola? $\mathrm{O}$ budismo e sua prática meditativa ensinam as pessoas a apreciarem o "aqui e agora" em busca de plenitude, um aprendizado em flagrante contraste com o consumismo das sociedades de mercado que precisam desenvolver nas pessoas um sentimento de urgência e necessidade voraz a fim de que acumulem produtos, reforçando o contraste com o desapego budista. Há muitos saberes que iluminam as relações humanas modernas para compreender como várias sociedades tradicionais lidam com problemas de nossa sociedade como a esterilidade, a homossexualidade, as religiosidades, etc.

Em vista disso, a primeira implicação do ponto de vista antropológico da educação é que a noção de formação humana é entendida de forma mais ampla. Nesse sentido, ela não é sinônimo de socialização estritamente no sentido de que as sociedades transmitem valores particulares através da 
educação, os quais serão compartilhados formando um "nós" cultural. A formação humana também não se reduz a representações racionalizadas e enquadradas por um dever ser, mas em aberturas cognitivas para dimensões poéticas, emocionais, pulsionais, vivenciais, inefáveis por natureza, abertas às possibilidades de um vir-a-ser.

É inegável a herança da antropologia para pensar a formação humana como educação não essencializada que, ao longo de sua história, acumulou etnografias das mais variadas sociedades e coletividades humanas. Muitas dessas sociedades são as chamadas "sem escrita", organizadas pela experiência, que educam por meio do exemplo e são marcadas por um tempo efetivamente vivido. Essas sociedades ainda subsistem ao lado das sociedades complexas, estas com suas abstrações, seus guias educativos e seu tempo limitado pelas horas do relógio.

Ao longo de sua história, a antropologia abriu-se para esquadrinhar as culturas, a fim de compreender e acolher as diferenças, isto é, reconheceu que a diversidade cultural é uma vantagem humana. Mas para que essa contribuição às futuras gerações se traduza em uma pedagogia para a formação humana, terá ela mesma que compreender os seus impasses e superar suas divisões.

Cultura, culturas e formação humana ${ }^{3}$

Por que não somos todos irmãos com irmãos?

Dostoiewsky

Identifico certa confusão quanto ao entendimento da palavra cultura. $\mathrm{Na}$ verdade, poder-se-ia dizer que há duas compreensões possíveis: como

\footnotetext{
${ }^{3}$ A discussão sobre as noções de cultura presentes na Antropologia requer um tempo maior. De qualquer modo, a primeira acepção, no final do séc. XVIII, está contida na palavra alemã Kultur, que foi tomada como o conjunto de aspectos espirituais de uma coletividade. Já a palavra francesa Civilization remete a seus aspectos materiais. A síntese dessas duas acepções foi formulada pelo evolucionista inglês, Edward Tylor: "Cultura, ou civilização, tomada em seu sentido etnográfico, é este todo complexo que inclui conhecimentos, crenças, arte, moral, leis, costumes ou qualquer outra capacidade ou hábitos adquiridos pelo homem como membro de uma sociedade". (Cf. LARAIA, 2009).
} 
"Cultura" ou como "culturas". Embora existam verdadeiros times de antropólogos em torno de uma definição ou outra, ambas concorrem para o esclarecimento dessa confusão. Não é meu propósito, no entanto, estabelecer uma hierarquia entre os conceitos, mas sim, ao distinguir as duas noções, poder defender uma unidualidade conceitual, mais apropriada ao que hoje sabemos sobre os aspectos complexos da condição humana (MORIN, 2001). Cultura é, ao mesmo tempo, universal e particular.

O conceito de cultura foi se desenvolvendo, ao longo da história da antropologia, na medida em que ia se tornando ciência a partir do final do século XIX, e que compreendia o seu papel no jogo da ocidentalização do mundo, desde os tempos dos exploradores e viajantes, que faziam rudimentares etnografias no século XVI, ao descreverem os costumes e modos de ser de várias culturas. $\mathrm{Na}$ autocrítica da antropologia, principalmente a partir da escola culturalista de Franz Boas, nos anos 30 do século XX, já constituída como ciência, pesou o fornecimento do conhecimento sobre as culturas como instrumento de dominação dos Estados Nacionais.

Nas discussões inicias da antropologia, a noção de cultura foi distorcida, uma vez que identificou a superioridade de todo o acervo de bens materiais e espirituais do Ocidente com a própria Cultura, o ápice da evolução humana, estágio supremo que todas as sociedades inelutavelmente iriam alcançar. Cultura é, pois, nessa acepção, igualada à civilização, aos valores do Ocidente. Nesse plano de pretensão universal de civilização, construiu-se um conceito de "Cultura" no singular, com "c" maiúsculo, apesar de essa perspectiva sofrer uma espécie de depuração ao longo do tempo. Hoje, essa perspectiva conduz as discussões e pesquisas sobre a estrutura geral da mente humana.

A crítica antropológica sobre o papel da antropologia na submissão dos povos colonizados, feita a partir da década de 60 , principalmente dos trabalhos pós-colonialistas de Frantz Fanon (1961), fez enunciar noções de

\footnotetext{
${ }^{4}$ Cultura com "C" maiúsculo é a resultante do processo evolutivo biológico; refere-se a uma estrutura com potencialidade para criar universos simbólicos.
} 
culturas como expressões de alteridade e de diversidade humana, ao mesmo tempo em que a denunciava como instrumento na dominação dos povos. Cultura aqui é sempre plural, "culturas" e com "c" minúsculo, uma vez que não existe critério que possa valorá-las, a não ser que um povo tenha o claro propósito de ações para dominar outro povo. Isto é, todo critério de hierarquização é político, arbitrário, como parte que é de um projeto hegemônico de poder, onde a escolha pode se dar pelo estabelecimento de superioridade de casta, de raça ou de classe. Essa recepção do outro na teoria antropológica, que se inicia em Malinowski, passando por Boas, é chamada de relativismo cultural, sendo que, a sua mais extrema concepção está presente nos trabalhos de Geertz, e que sofreu, e ainda sofre, críticas, uma vez que declara a inacessibilidade do conhecimento antropológico às culturas.

De forma mais detida, do que foi dito anteriormente é possível traçar duas linhas no pensamento antropológico conforme suas concepções de cultura. Uma linha segue os moldes do evolucionismo cultural de Tylor, Frazer e Morgan (Castro, 2009) que procurava estabelecer uma psique humana universal, compreendendo "Cultura" como civilização. Para isso, tomou como parâmetro a sociedade europeia, branca, monogâmica, cristã e urbana, e a igualou à civilização, como foi dito anteriormente, para classificar as demais sociedades, a depender dos sinais de evolução de suas técnicas, categorizando-as como selvagens ou bárbaras. Ao fazer uma transposição automática do modelo evolutivo biológico de Charles Darwin para o "evolucionismo" cultural, a antropologia acabou produzindo nos seus primórdios noções preconceituosas, que facilitariam o neocolonialismo dos povos menos “evoluídos” da África.

Mas com as pesquisas antropológicas do pioneiro Malinowski (1976), em Argonautas do Pacífico, a compreensão de "culturas", no sentido de alteridade, se dá à luz dos estudos de campo, por meio da observação e da imersão do pesquisador numa cultura específica estudada, e só dessa forma a cultura se faz compreensível em seus próprios nexos sociais. Franz Boas (1931) também entendia que não era possível estabelecer uma relação de dependência entre raça e cultura, e ao inescapável sentido da evolução 
delineado pelo darwinismo social, ele contrapôs o conceito de particularismo histórico. Isto é, as culturas têm mecanismos que controlam o sentido das mudanças admissíveis para uma sociedade particular. Os trabalhos de suas alunas Ruth Benedict (1983) e Margareth Mead (1999) mostraram que os humanos aprendem a ser humanos de forma particular. As sociedades estabelecem padrões de educação cujos conteúdos são transmitidos de geração a geração. Formar um ser humano significa que uma sociedade deve ser bem sucedida em sua tarefa cultural de atingir um padrão inscrito em suas particularidades, em sua forma peculiar de ser e existir. Em suma, cultura para esses antropólogos passa a ser compreendida no plural, como "culturas", pois a diversidade implica, necessariamente, pluralidade e singularidade de cada padrão cultural.

Claude Lévi-Strauss (1970), a partir dos estudos sobre a linguagem de Ferdinand Saussure, volta ao tema da universalidade da cultura ao mostrar o caráter estrutural e estruturante da mente humana. Para o antropólogo, os mitos, por exemplo, estariam a falar sempre da oposição entre natureza e cultura na vida humana, já que eles são representações mentais e, onde quer que se encontre um humano, a despeito de suas diferenças aparentes, ele possui a mesma estrutura mental que outros seres humanos: todos possuem as mesmas aptidões para pensar, conceber, inventar, imaginar. Os mitos, então, são representações da estrutura mental humana, sistemas codificados de maneira binária e por oposição, natureza x cultura, que visam a responder culturalmente a questões relativas ao acoplamento biológico, à sua condição natural.

$\mathrm{Na}$ perspectiva da antropologia de Lévi-Strauss (1970), a mente humana e sua forma de operar é universal pois, uma vez que pensamos pelos mesmos aparatos cerebrais, as variações culturais seriam apenas aparentes. Os vários mitos, religiões, crenças e sistemas filosóficos, assim, enfrentariam questões cruciais a todos sobre a existência humana. À finitude do corpo, às necessidades fisiológicas, aos aspectos mais prosaicos da existência, os humanos contrapõem as criações culturais, coletivas, transmissíveis e, por 
isso, na medida em que somos todos humanos, podemos compreender os discursos, uns dos outros, o dito e o não dito, o implícito e o explícito.

Mas, para a antropologia interpretativa de Geertz (1989), as culturas são textos cujos sentidos só podem ser apreendidos por elas mesmas, pois elas guardam uma lógica irredutível à compreensão do antropólogo, que nada mais seria do que um etnógrafo e nada mais faria do que uma descrição densa. Não é possível para a antropologia, nessa perspectiva, apreender uma unidade humana como fazem os estruturalistas. A ideia de "culturas" encerra, por isso, para os semioticistas da cultura, um extremo relativismo. Poder-se-ia argumentar, dessa forma, que a diversidade cultural estaria mais próxima da ideia de coexistência de alienígenas incompreensíveis uns para os outros.

Ainda que a divisão entre os defensores das noções de "Cultura" e de “culturas" esteja presente nos departamentos de antropologia, formando verdadeiros guetos em favor do universalismo ou do relativismo cultural, há hoje uma abertura representada pelas reflexões de Edgar Morin (1975), iniciadas em $O$ enigma do homem, sobre a unidualidade da condição humana. Nesse livro, o pensador francês se ancora em estudos arqueológicos, na antropologia física, na biologia e na pré-história para demonstrar que a constituição biológica do Homo sapiens o empurra para a cultura, para a criação de artifícios para a sobrevivência da espécie e, também, para o refinamento de técnicas para sobrevivência baseadas mais na inteligência do que na força bruta de outras espécies como, por exemplo, os neanderthalensis, que coexistiram com os sapiens e que, provavelmente, tenham sido extintos por estes últimos há milhares de anos. No entanto, a sapientalidade humana depende da transmissão do que é sabido, da herança cognitiva dos mais velhos transmitidos aos mais jovens, através da aprendizagem. Os humanos têm um cérebro desenvolvido para aprender, um aparelho fonológico para transmitir informações e todos os sentidos adaptados para essa tarefa tão complexa.

O processo de hominização, no entanto, é sempre inacabado porque, como ser biológico, o homem está em evolução, seus genes são passíveis de mutação. Não sabemos em que sentido o humano está evoluindo, mas 
sabemos que a evolução sempre responde a necessidades da espécie de se adaptar às condições do meio natural ou social, o que torna a existência humana no planeta uma aventura, algo indeterminado e permeado por incertezas de toda ordem: o futuro, então, não está garantido. A sobrevivência do sapiens depende não apenas de sua inteligência, mas também do exterior; ele precisa obter alimentação, abrigo, ter segurança e condições favoráveis de existência enquanto espécie no planeta, isto é, não é possível garantir que os humanos sejam sempre providos em suas necessidades, uma vez que sabemos que os recursos naturais são finitos. Em suma, precisamos admitir que a autonomia humana no mundo é limitada, pois os humanos se submetem a todas as vicissitudes da existência por serem auto-eco-dependentes.

Já o processo de humanização se refere à forma como nos tornamos humanos. A evolução, ou o processo de hominização, guarda latentes as possibilidades da espécie, como andar bípede, falar, pensar, etc. A humanização também não é certa porque depende da transmissão dos valores culturais (materiais, espirituais e estéticos) por meio da linguagem, de arranjos infinitos entre as pessoas, isto é, de que as capacidades latentes se realizem através das interações sociais. Portanto, a humanização depende de um processo relacional entre as capacidades latentes da espécie e o mundo, a realidade, efetivado pela aprendizagem em que a linguagem tem um peso decisivo. Por isso, não se pode falar em determinação biológica para os humanos, como se fala em relação a outros animais, cujas respostas às imposições do meio estão inscritas em seus genes. Assim, a humanização depende da cultura que pode alterar os condicionamentos de ordem biológica. Em vista do que foi exposto, apreende-se que aprender um universo cultural significa estar inescapavelmente inserido numa sociedade dotada de padrões culturais particulares. As "culturas", como universos simbólicos particulares, dizem de que forma nos tornamos humanos. O processo que chamamos de endoculturação, o aprendizado de uma cultura particular, não separa cultura de educação e, por causa dessa relação de interdependência, é crucial para a humanização. Um integrante da etnia Munduruku aprende a ser humano de forma particular, na cultura Munduruku onde ele está inserido, como também 
os Inuit, habitantes do Ártico, ou os urbanos das cidades grandes. Mas sem a condição geral estruturante da Cultura possibilitada pelo aparato biológico, que pode ser alterado por imposições de ordem cultural, ninguém pode ser humano. Aí está o anel recursivo antropológico: a cultura constituiu o humano que, por sua vez, recria a cultura.

A dialogia universal/particular no que se refere à "Cultura" e às “culturas", referentes à estrutura humana geral para produzir sistemas simbólicos e a sua dependência de aprendizagens específicas, ata-as irrevogavelmente. Assim, a constituição humana, no sentido biológico (hominização) também está relacionada à formação humana (humanização) que depende de processos educativos. Hominização e humanização concorrem, pois, para a educação de uma forma geral (todas as sociedades educam os seus membros) e de forma particular (as sociedades educam dentro de modelos culturais específicos).

Outra implicação dessas reflexões diz que a dialogia Cultura/culturas é a base para o entendimento dos processos cognitivos, enquanto constituição dos aparatos biológicos para adquirir saberes importantes para viver. Diz também que não é possível qualquer processo de humanização sem tal aparato, e esse aparato só realiza o seu potencial inserido numa cultura particular, em que os operadores cognitivos acionam o universo simbólico das diferentes culturas por mediadores linguísticos. A formação humana, então, está subordinada aos arranjos linguísticos que a interação entre humanos possibilita.

Morin (2003) considera que a educação deve enfrentar os problemas contemporâneos e, para isso, precisa ensinar, entre outros saberes, a condição humana. O que isso significa? Que o homem é, ao mesmo tempo, natureza e cultura; e que tem um cérebro complexo (reptílico, mamífero, racional) resultante de um processo evolutivo, que constitui o processo hominização/humanização. O ensino da condição humana (MORIN, 2001) considera os limites da espécie, suas indeterminações contrastadas às certezas perseguidas pela ciência no paradigma ocidental. Por fim, ensinar a condição 
humana é dotar a formação da consciência dos domínios apolíneo/dionisíaco na construção de uma antropoética.

A espiritualidade

$$
\begin{aligned}
& \text { As palavras comportam-se como seres } \\
& \text { caprichosos. } \\
& \text { Otávio Paz } \\
& \text { Physis é, antes de mais nada, o título de } \\
& \text { uma questão: "De onde vêm as coisas? } \\
& \text { Como elas nascem e crescem?" } \\
& \text { P. Albuquerque }
\end{aligned}
$$

Diante do que foi exposto anteriormente sobre a base biocultural, a evolução biológica, a hominização, sobre a qual a humanização se realiza, como compreender a espiritualidade humana? O entendimento mais imediato e mais simplista é de que há uma instância espiritual quase autônoma, exterior e estranha à concretude da vida humana. Essa compreensão, embora se submeta a uma crítica, envolve aspectos do desenvolvimento do pensamento ocidental que é necessário explicitar na afirmação, até aqui implícita, de que a espiritualidade humana é imanente ao mundo material.

A noção de espiritualidade é permeada pelo pensamento platônico da separação entre um mundo inteligível pleno, espiritual, e outro corporal e imperfeito, o mundo sensível. No entanto, quando adotamos uma perspectiva antropológica, de interdependência de natureza e cultura, de inseparabilidade da condição estrutural biológica que nos dota da capacidade de simbolizar, em que o universo da espiritualidade emerge das condições particulares em que ela se efetiva, surgem alguns questionamentos com relação ao sentido das proposições filosóficas clássicas transcendentes.

Seria possível qualquer manifestação do espírito humano sem um corpo? Uma resposta positiva ou negativa pode muito bem representar a divisão do pensamento ocidental em dois fronts, que eu resumo dessa forma: aqueles que acreditam que existe uma alma, que é uma espécie de sopro que 
anima um corpo que lhe dá vida; e aqueles que afirmam que o chamado espírito humano emerge das propriedades da matéria viva, da vida.

Ao primeiro grupo, que chamo de "pensadores da alma", contraponho as afirmativas da ciência de que a matéria concorre para a produção da vida e sua evolução jamais implica hierarquizar a natureza em que a espécie humana está no ápice, nem a ideia de que valores morais estariam regendo a evolução da humanidade no sentido espiritual. Ao admitir essa hierarquia teríamos que aceitar que um ser maior, transcendente, de forma totalmente arbitrária, teria os critérios para tal classificação. Estaríamos à mercê de um ser que não se dá a conhecer.

Essa posição cada vez mais presente nas escolas e nas universidades, incentivada por líderes religiosos que defendem até o ensino da "teoria criacionista", concorrente com a teoria da evolução biológica, tenta revogar o que disse Freud sobre a ferida narcísica aberta em três momentos do conhecimento. A primeira aconteceu quando Copérnico declarou que nem a Terra nem o homem era o centro do Universo. A segunda ferida foi aberta quando Darwin inseriu o homem no grande quadro classificatório dos seres da natureza, nem melhor, nem maior que outras espécies. A terceira ferida foi aberta pelo próprio Freud, uma vez que demonstrou que o inconsciente governa e determina os atos humanos na maioria das vezes.

De forma quase aparentada, ainda que mais adaptada aos nossos tempos, uma perspectiva tributária da filosofia platônica de transmigração das almas, segundo a qual as ideias têm autonomia e prescindem do mundo sensível, é, por vezes, aceita nos meios acadêmicos. Na verdade, ao adotar a perspectiva da supremacia da alma, portanto, do humano sobre a natureza, os pensadores da alma necessariamente assumem uma visão dogmática, uma vez que o mundo da espiritualidade seria igual ao mundo da religiosidade. O que reforça esse parentesco seria um criacionismo (creatio ex nihilo) que confirmaria tanto a superioridade do homem no seio da criação, como a afirmação de ser especial no reino animal, imprimindo à espiritualidade humana uma marca divina. Portanto, para os pensadores da alma, espiritualidade, religião e criação estão intimamente conectadas. 
Parece difícil ao pensamento ocidental abandonar ideias e ações da superioridade do homem predestinado a controlar e submeter a natureza à sua vontade. Mas essa crença na supremacia dos humanos no mundo também é tributária do ideário evolucionista do século XIX, que popularizou suas afirmações as quais ainda hoje se encontram nas várias instituições encarregadas de educar. Acredita-se que a tarefa de educar e levar os povos "atrasados" à "civilização" coube, e ainda cabe, aos "mais evoluídos", ao mais aptos, aos superiores, se levarmos em conta as crescentes demonstrações de supremacistas brancos e de discriminação racial e cultural. Nota-se, portanto, que essa ideia permeia o pensamento contemporâneo quando emerge nos discursos políticos nacionalistas. Acrescenta-se a isso a persistência da ideia de que os humanos devem se sobrepor a uma natureza exaurida. A supremacia dos humanos e dos "civilizados", à revelia do que foi dito, é garantida por pensadores e cientistas que afirmam veementemente que a ciência será capaz de garantir a sustentabilidade de um planeta já insustentável.

É difícil para os ocidentais reconhecer que outras culturas foram, e têm sido, mais bem-sucedidas na relação que estabelecem com o meio, justamente porque elas formam um "tecido inteiriço natureza-culturas", denominação utilizada por Bruno Latour $(1994$, p.12) quando se refere a questões para uma antropologia simétrica. O Ocidente "civilizador" não considera a legitimidade de outros modelos culturais. Pode aceitar que sociedades não escolares socializem seus membros, mas sua socialização, segundo esses civilizadores, não visa propriamente a uma formação humana, pois esta só pode se referir aos altos ideais do Ocidente. Mas, o que seria formação humana se não um projeto de futuro para a sociedade, presente nos saberes das tradições, em suas narrativas orais, em seus repertórios de ensinamentos? É preciso interpretar os seus ensinamentos à luz das necessidades humanas, da experiência, a partir de uma curiosidade simples: como outros povos e culturas resolvem problemas que precisamos resolver e somos incapazes até o momento de resolvê-los? 
Já aos pensadores da physis cabe a tarefa de pensar o primado da matéria na supremacia do espírito, solução dada ao problema aqui abordado por André Comte-Sponville (2002), pois o corpo inscreve e, ao mesmo tempo, dele emerge a espiritualidade humana. O corpo é, o corpo pensa. Essas afirmações se inspiram na fenomenologia de Merleau-Ponty e na filosofia da imanência de Spinoza. A justificativa é que não podemos apreender o mundo de outra forma. A atribuição de natureza transcendente à espiritualidade está amputada de corpo, de matéria e de vida. Não se pode afirmar nada sobre a origem do mundo, no entanto, cria-se e constrói-se o mundo das ideias, de seres imaginários, de esquemas, conceitos, paradigmas, mitos, etc. para preencher a angústia antropológica fundamental: a consciência da morte individual. Mas esse mundo das ideias não prescinde do corpo, dele emerge e é imanente da dinâmica da vida e da matéria.

Como se constitui, então, o mundo da espiritualidade, a partir da compreensão enunciada? Tomo aqui a ideia de espiritualidade inserida na noção de Noosfera exposta na obra de Teilhard de Chardin. No entanto, é preciso esclarecer que não se trata de assumir a ideia de noosfera desse autor, tout court. Como a própria palavra indica, ela é aqui utilizada desprovida de conotação religiosa, como pensamento humano.

Teilhard de Chardin (s.d.) esforçou-se em relacionar criação e evolução, compreendendo que a evolução supõe a criação, da biogênese à hominização ou antropogênese. A linha evolutiva, matéria, vida e espírito, culmina na supremacia da noosfera, cuja expansão visa à interação do indivíduo à cultura e tem por síntese a busca da personalidade coletiva. $\mathrm{O}$ teólogo chama a atenção para a condição humana, de um lado física, natural e de outro sociocultural (Urbano, 2001, p. 59). O que se impõe a seu pensamento, no entanto, é que toda a evolução estaria implicada na ideia de que deus é o ômega de toda a evolução, que não seria nada mais do que a história da criação.

Mas, abstraído o fim divino de suas reflexões, Chardin incita a pensar na espiritualidade articulada à cultura e é, nesse sentido, que Morin retoma a ideia de noosfera formulada da seguinte forma: 
As representações, símbolos, mitos, ideias, são englobados, ao mesmo tempo, pelas noções de cultura e de noosfera. Do ponto de vista da cultura, constituem a sua memória, os seus saberes, os seus programas, as suas crenças, os seus valores, as suas normas. Do ponto de vista da noosfera, são entidades feitas de substância espiritual e dotadas de certa existência (MORIN, 2008, p. 139).

As características que dão contorno a essa dialogia cultura-noosfera, segundo Morin, guardam uma relação do imaginário com a dimensão antropossocial. A noosfera é habitada por seres espirituais, que guardam relações de autonomia/dependência, de simbiose e parasitismo, com a esfera antropossocial da qual fazem parte:

Todas as entidades noológicas duráveis são auto-eco-organizadoras (o ecossistema, onde se elaboram e reproduzem os mitos e as ideias, é constituído pelo meio cultural e pelos espíritos/cérebros); todas dispõem, inclusive mitos e religiões, de uma maquinaria complexa constituída por uma linguagem, uma lógica e, mais profundamente, vinculam-se a uma paradigmática (IB., p. 143).

O que isso quer dizer? Que criamos os seres que nos controlam, nos dominam, por isso eles parecem ter vida própria, ter autonomia absoluta. A espiritualidade a partir das noções de noosfera e cultura confere um sentido mais humano ao que fazemos, às nossas criações e à seiva de onde ela se alimenta, nossas culturas. Os mitos, os conceitos, as crenças não escapam da condição de seres do mundo da espiritualidade humana. Nesse sentido, é deus não um fim na evolução, mas um ser da noosfera, uma criação humana. Há uma relação de dependência inescapável dos seres do espírito com a realidade, com a sociedade e com as "culturas", de pessoas reais em seus dilemas existenciais.

Essas ideias implicam dizer que a formação humana, enquanto processo educativo, depende, em grande parte, de que essa dinâmica 
imaginário-cultura seja trazida à consciência, isto é, desvelada por meio da educação. A tarefa favoreceria a compreensão de que o mundo das ideias é habitado por saberes necessários ao enfrentamento de problemas vivenciados ou que se irá vivenciar. A condição matéria-espírito, compreendida na dinâmica imaginário-cultura, deixa para os humanos a responsabilidade da construção da noosfera para os desafios da contemporaneidade, que vão da convivência na diversidade cultural aos imperativos da solidariedade no planeta para a conservação da espécie e para a distribuição de suas riquezas. Portanto, a espiritualidade, como emergência antropossocial, isto é, acoplada na natureza e, ao mesmo tempo, no mundo cultural é, e talvez seja, a sua ideia mais bem-acabada, mas essencialmente caída, com a saída dos humanos do paraíso divino para habitar um mundo real, mas cheio de possibilidades e de recriação.

\title{
Antropoética
}

\author{
A ética [...] continua problemática, ou seja, \\ cria problema, o que nos obriga a pensar. \\ Kostas Axelos \\ O seu imperativo [da ética] origina-se \\ numa fonte interior ao indivíduo que o \\ sente no espírito como injunção de um \\ dever. Mas ele provém também de uma \\ fonte exterior: a cultura, as crenças, as \\ normas de uma comunidade.
}

Edgar Morin

Muss es sein? Es muss sein!

Beethoven

A ideia caída de formação humana significa pensar uma ética de humanidade mais próxima do barro, da experiência humana, do que do sopro, como inspiração estranha aos humanos. Portanto, pensar a formação humana de um ponto de vista antropológico resulta, ainda que não seja a sua tarefa principal, 
numa ética para enfrentamento de problemas contemporâneos, principalmente com relação à luta pela humanização do pensamento como resistência a uma educação tecnocientífica voltada para satisfazer propósitos econômicos e financeiros de produtividade.

Em $O$ método 6: a ética, Morin diz que a ética é pensada como imperativo de religação ${ }^{5}$ :

Todo olhar sobre a ética deve perceber que o ato moral é um ato individual de religação; religação com o outro, religação com uma comunidade, religação com uma sociedade e, no limite, religação com a espécie humana (MORIN, 2005, p.21).

Para o pensador francês, os fundamentos da ética estão em crise no mundo ocidental; uma crise que é também do conhecimento filosófico e científico. Seus sintomas se fazem sentir pelo egocentrismo, pela degradação da solidariedade, pela burocratização e pela atomização da vida social; pelas variadas formas de corrupção, em que o individualismo se sobrepõe ao sentido de coletividade e à espécie. Para Morin, é preciso retomar a discussão sobre a origem, sobre a physis, e pensar sobre uma religação antropológica. É importante notar no autor a construção de uma argumentação epistemológica que começa justamente pela physis no primeiro volume da obra $O$ Método 1: a vida da vida que vai se desenrolando nos demais livros até chegar inevitavelmente a $O$ método 6: ética. O autor compõe três instâncias da ética complexa, que comporta: uma autoética, uma socioética e uma antropoética. A autoética diz respeito ao desenvolvimento da consciência e a decisões pessoais quando o indivíduo experimenta uma exigência moral. Ela se alimenta de mananciais vivos psicoafetivos, antropológicos, sociológicos e culturais.

\footnotetext{
${ }^{5}$ Morin adota o termo religação conforme a noção inventada pelo sociólogo Marcel Bolle, que a substantiva e confere à palavra um sentido ativante e oposto à palavra desligação, de separação. Opõe ele, assim, as forças de integração, como o amor, às forças do diabolus, separador.
} 
A socioética, ou ética da comunidade, caracteriza-se pelo sentimento de dever na direção da solidariedade e da responsabilidade. Ela se impõe por si mesma nas sociedades tradicionais, mas de maneira irregular nas sociedades complexas, ou sob a grande comunidade do Estado-Nação. Com essa crise dos liames do indivíduo na sua "tribo", o despertar da autoética é de fundamental importância numa democracia cognitiva (MORIN, 2001), uma vez que se sente cada vez mais premente a necessidade de se desenvolver estratégias de acesso do cidadão comum a um conhecimento socializado e politicamente qualificado sobre o uso das tecnologias de informação. Hoje, estas estão sob o domínio de experts, geralmente incompetentes para compreender o quadro social onde elas se inserem, cujas implicações políticas são ocultar interesses que, muitas vezes, se contrapõem à sociedade, ao indivíduo e à espécie. Fala-se também de uma era pós-verdade, ou ainda pósfatos, uma vez que os dados da realidade são manipuláveis de tal sorte por técnicas de diagramação de mídia, que as fabulações disputam politicamente um sentido de verdade. É nesse sentido que a democracia dos usos da tecnologia é, sobretudo, uma discussão ética de implicação política.

Autoética e socioética estão implicadas na formação humana. O educador japonês Tsunesaburo Makiguti (2002), com uma perspectiva antropossocial da educação, inseriu as dimensões éticas da formação humana em um sistema pedagógico que chamou de "bem, benefício e beleza" por contemplar as três facetas com as quais podemos pensar Cultura/culturas: como um campo de criação de valores materiais, coletivos e individuais. Caberia ao educador, então, dirigir seus ensinos para proposições éticas.

A antropoética ou ética do gênero humano, segundo Morin, é o reconhecimento da unidade do humano em suas antinomias e plenitude:

(A antropoética) ergue no nível ético a consciência antropológica que reconhece a unidade de tudo o que é humano na sua diversidade e a diversidade em tudo o que é unidade: daí a missão de salvaguardar por toda parte a unidade e a diversidade humanas. A antropoética liga a ética universal e a ética do singular [...] A ética universalista, tornada concreta, é antropoética (2001, p. 160). 
A antropoética requer a religação de saberes, apartados pela extrema disciplinarização e fragmentação do conhecimento, pelo reducionismo metodológico e pela superespecialização. A tarefa de recuperar a socioética deve começar com a autoética, uma forma complexa de operar o conhecimento de si e do outro que requer uma reforma do pensamento, segundo Morin (id.). Mas antes, ela exige, ainda, uma reforma dos educadores, como já advertia Karl Marx na terceira tese sobre Feuerbach. A antropoética é uma resposta possível aos imperativos da convivência humana no planeta. Como compreensão encarnada/incorporada na dialogia natureza/cultura, a relação entre antropologia e ética pode ser pensada como uma pedagogia da convivência em um mundo que parece ressuscitar ideologias de segregação, discriminação e genocídios.

\section{O tecido}

Para concluir, recupero os fios do que foi tecido sobre formação humana, costurados sobre uma tela de fundo antropológico.

Meu argumento de que é preciso pensar a formação humana de uma forma mais alargada considera a educação como um fato da vida humana, sem o qual não é possível nenhum humano se tornar propriamente humano sem realizar as potencialidades latentes da espécie. A Cultura estrutura a condição humana e as culturas são versões possíveis da vida no mundo. Ambas estão de tal forma relacionadas que, ao entendê-las separadamente, tem-se uma versão amputada do próprio humano.

Por isso, não é possível estabelecer uma hierarquia entre as culturas. Ao olhar para as diversas culturas e sua teia inteiriça natureza-culturas, a antropologia consegue desvelar modelos cognitivos de outras sociedades, as quais sabem lidar com problemas de organização social, com as religiosidades, com as formas de subsistência, com questões relacionadas à diversidade de gênero e com a sexualidade como fatos da vida desprovidos de guias morais. Assim, as diversas formas de conviver e de responder aos problemas do contexto podem ser um manancial de inspirações aos desafios 
das sociedades complexas. Trata-se, então, de um movimento contrário àquele que pensaram os evolucionistas em relação às sociedades ditas primitivas: não são as sociedades ocidentais que normatizarão e civilizarão as sociedades simples. Ao contrário, nossos problemas demandam soluções que as sociedades simples já conhecem e resolvem de forma pragmática. Uma vez que admitimos que os saberes, ritos, teorias, deuses, religiões, os seres da noosfera, emergem das interações humanas, das sociedades e das culturas, parece-me crucial considerarmos, ou conseguirmos enxergar, outras culturas como representações variadas do humano, reveladas em universos simbólicos e formas particulares de compreender o mundo.

Por fim, pensar a formação humana talvez signifique abandonar a ideia de que só as escolas têm legitimidade para a tarefa de educar, pois a noção de antropoética abarca dimensões da formação humana não essencializadas e não formalizadas. Essa formação encerra a noção de condição antropológica do sapiens, natural e cultural e, ao mesmo tempo, uma ética encarnada, imanente à vida, à experiência, à diversidade humana e cultural. A formação humana que aqui se delineia com base numa antropoética abriga, dessa forma, o relativo e o universal do humano, sobretudo, indaga como sermos humanos e como buscarmos a humanidade de que precisamos num mundo possível de ser habitado.

\section{Referências}

BENEDICT, Ruth. Padrões de Cultura. São Paulo: Livros do Brasil, 1983.

CASTRO, Celso (org.). Evolucionismo cultural: textos de Morgan, Tylor e Frazer.

Rio de Janeiro, Jorge Zahar, 2009.

CHARDIN, Teilhard de. O fenômeno bumano. São Paulo: Cultrix, s.d.

COMTE-SPONVILLE, André. O alegre desespero. São Paulo: Editora UNESP;

Belém, PA: Editora da Universidade Estadual do Pará, 2002.

FANON, Frantz. Os condenados da Terra. Lisboa: Ulisseia, 1961.

LARAIA, Roque de Barros. Cultura: um conceito antropológico. Rio de Janeiro: Zahar, 2009. 
LARROSA, Jorge. Niețssche e a educação. Belo Horizonte: Autêntica, 2005.

LATOUR, Bruno. Jamais fomos modernos: ensaio de antropologia simétrica. Rio de Janeiro: Ed. 34, 1994.

LÉVI-STRAUSS, Claude. Natureza e cultura. In: As estruturas elementares do parentesco. Petrópolis: Vozes, 2009.

- A antropologia diante dos problemas modernos. São Paulo: Companhia das

Letras, 2012.

O pensamento selvagem. São Paulo, Ed. Nacional, 1970.

MAKIGUTI, Tsunesaburo. Educação para uma vida criativa. São Paulo: Record, 1995.

MALINOWSKI, Bronislaw. Argonautas do Pacifico Ocidental. São Paulo: Abril Cultural, 1976.

MEAD, Margaret. Sexo e temperamento em três sociedades primitivas. São Paulo: Perspectiva, 1999.

MORIN, Edgar. Os sete saberes para a educaşão do futuro. São Paulo: Cortez; DF UNESCO, 2001.

- O método 3: o conhecimento do conhecimento. Porto Alegre: Sulina, 2003.

. O método 4: as ideias. Porto Alegre: Sulina, 2008.

. O método 6: ética. Porto Alegre: Sulina, 2005.

. O enigma do homem: para uma nova antropologia. Rio de Janeiro: Zahar, 1975.

PRIGOGINE, Ilya. Ciência, razãa e paixão. (Orgs. Maria da Conceição Almeida e Edgard de Assis Carvalho). Belém: EDUEPA, 2001.

URBANO, Zilles. Pierre Teilhard de Chardin: ciência e fé. Porto Alegre: EDIPUCRS, 2001. 